\title{
Influence of low cadmium and zinc concentrations on batch culture Prorocentrum micans (Dinophyta) containing low levels of dissolved organic carbon
}

\author{
U. Rabsch, K. Wolter and P. Krischker
}

Institut für Meereskunde an der Universität Kiel, Düsternbrooker Weg 20, D-2300 Kiel 1, Federal Republic of Germany

\begin{abstract}
Experiments with Prorocentrum micans Ehrenberg were run over a period of $380 \mathrm{~h}$ in North Sea water containing $0.5 \mathrm{mg} \mathrm{Cl} \mathrm{l}^{-1}$ of dissolved organic carbon. Dissolved Cd concentrations ranged from 0.08 to $10 \mu \mathrm{g} \mathrm{l}^{-1}$; Zn concentration was $0.1 \mu \mathrm{g} \mathrm{I}^{-1}$. Cell density started with $35000 \mathrm{l}^{-1}$. Growth in terms of cell numbers, primary productivity, bacterial activity, and uptake of $\mathrm{Zn}$ and $\mathrm{Cd}-$ measured by the radio isotopes ${ }^{65} \mathrm{Zn}$ and ${ }^{109} \mathrm{Cd}$ - were followed in short intervals during exponential and stationary growth phases. Enrichment factors of the metals were highest at the lowest $\mathrm{Cd}$ concentration. On a daily basis, $\mathrm{Cd}$ and $\mathrm{Zn}$ concentrations increased during the day and decreased at night. The rhythm was most obvious during exponential growth. This indicates the special role of actively metabolising cells for uptake of $\mathrm{Zn}$ and $\mathrm{Cd}$. Accumulation was more rapid for $\mathrm{Zn}$ (maxima every $24 \mathrm{~h}$ ) than for $\mathrm{Cd}$ (maxima every $26 \mathrm{~h}$ ), so that the daily rhythm of the metals was shifted.
\end{abstract}

\section{INTRODUCTION}

Numerous investigations with uni-algal phytoplankton cultures (e.g. Berland, 1977; Kayser, 1977; Prévot, 1978a, b; Saifullah, 1978; Kayser and Sperling, 1980; Rabsch and Elbrächter, 1980), as well as with natural phytoplankton (e.g. Rajendran et al., 1978; Fisher and Jones, 1981; Subba Rao, 1981) have shown that even low concentrations of heavy metals can affect phytoplankton.

The degree of toxicity depends on several factors: (1) nature of metal contamination - most investigations showed higher toxicity for $\mathrm{Hg}$ and $\mathrm{Cu}$ than for $\mathrm{Cd}$ or $\mathrm{Zn}$ in algae (Rai et al., 1981); (2) metal speciation which is determined by environmental factors such as $\mathrm{pH}$, chlorinity, calcium, phosphorus, dissolved organic matter concentrations, etc.; heavy metals seem to be available to algae only in cationic forms (Davies, 1978; Canterford and Canterford, 1980; Møhlenberg and Jensen, 1980; Rai et al., 1981); (3) concentration of bio-available species; (4) population density: the amount of metal ions in solution may be depleted at high population densities by accumulation and complexation of metals by exudates; the degree of toxicity, however, is a function of metal concentration in the cells (Davies, 1978).

(C) Inter-Research/Printed in F. R. Germany
These factors vary in natural waters. Toxic effects of metals depend on the combination of these factors. We studied the effect of naturally occurring $\mathrm{Zn}$ concentrations, combined with different $\mathrm{Cd}$ concentrations added to a non-axenic culture of Prorocentrum micans under controlled conditions of light, temperature and salinity. Cell concentrations at the beginning of experiments were kept low and organic material was removed from the seawater used in order to avoid the significant fraction of the metal being present in organically complexed forms. Effects of $\mathrm{Zn}$ and $\mathrm{Cd}$ were studied at the single-cell level from carbon fixation activity and metal accumulation by the cells. Development of the population was followed by cell counting and measurements of activity and metal accumulation by the cells during different phases of growth. We investigated the complete growth cycle because one inhibitory effect at the population level may be that it enters the stationary phase at significantly lower cell concentrations than the controls (Jensen and Rystad, 1974). Such studies elucidate the accumulation of $\mathrm{Zn}$ and $\mathrm{Cd}$ by the cells, the direct metabolic response of the single cell as well as of the effect on the whole population.

Similar to experiments carried out by Kayser and Sperling (1980) we investigated the development of 
the dinoflagellate Prorocentrum micans under the influence of $\mathrm{Zn}$ and $\mathrm{Cd}$ during long-term exposure. In addition, we also measured short intervals in an attempt to detect possible daily variations; measured cell activity; and used radioisotopes in DOC depleted water to follow metal uptake. P. micans was chosen because it occurs regularly during autumn in the Kiel Bight and because it is unicellular, thus facilitating a more even distribution in the culture medium than is possible with chain-forming species. Hence, cell counting is more accurate and the metal content can be better related to single cells. Finally, $P$. micans is known to be very sensitive to Cd (Prévot, 1978b). Another alga typical for this region, Coscinodiscus granii, often develops during spring and was investigated in an earlier study (Rabsch and Elbrächter, 1980).

During the growth cycle of Prorocentrum micans we carried out 3 intensive periods of measurements. During each period of $3 \times 24 \mathrm{~h}, 4$ samples were analysed every 1 to $2 \mathrm{~h}$. Between these periods only cell counts were made.

Sampling intervals were kept short in order to investigate the daily rhythm of metal accumulation and its relation to the photosynthetic activity of the cell. Changes of metabolic activity during day and night are well documented (Sweeney and Prézelin, 1978; Prézelin and Ley, 1980). Changes in algal sensitivity to $\mathrm{Zn}$ and $\mathrm{Cd}$ might parallel changes in culture conditions.

Bacteria associated with the algae developed during the experiment, affecting $\mathrm{Zn}$ and $\mathrm{Cd}$ concentrations. Therefore, bacterial activity was measured over longer time intervals by ${ }^{14} \mathrm{C}$-glucose incorporation.

\section{MATERIAL AND METHODS}

Prorocentrum micans Ehrenberg was obtained from the Plymouth culture collection. The dinoflagellate was maintained in water from List Deep at $29.5 \pm 0.5 \% \mathrm{~S}$, total $\mathrm{CO}_{2}$ content $\left(20 \mathrm{mg} \mathrm{Cl}^{-1}\right)$, and a low concentration of $\mathrm{DOC}\left(0.5 \mathrm{mg} \mathrm{Cl}^{-1}\right)$. The latter was obtained by filtering and passing the water through $0.2 \mu \mathrm{m}$ Sartorius membrane filters and a Millipore charcoal filter $7972 \mathrm{xx}$. The water was then partly sterilized by pasteurization. Autoclaving was avoided because of salt precipitation, which would occur during this procedure. Two long-term experiments were carried out over periods of 11 and $16 \mathrm{~d}$. Ten liter quartz bottles were filled with seawater and inoculated with algae, which had previously been maintained in the dark for $2 \mathrm{~d}$ to stimulate synchronized growth (Elbrächter, pers. comm.). Cadmium was added as diluted $\mathrm{CdCl}_{2}$ Titrisol standard (Merck) to produce 1, 2, and $10 \mu \mathrm{g} \mathrm{l}^{-1}$ concentration increases over the $0.08 \mu \mathrm{g} \mathrm{l}^{-1}$ background level.

Additionally, radioactive tracers ${ }^{109} \mathrm{Cd} \quad(74 \mathrm{kBq}$ [5.9 $\left.\mathrm{ng}]^{-1}\right)$, and ${ }^{65} \mathrm{Zn}\left(222 \mathrm{kBq}[15.5 \mathrm{ng}]^{-1}\right)$ were added, resulting in a total $\mathrm{Zn}$ concentration of $0.1 \mu \mathrm{g} \mathrm{l}^{-1}$. The control contained only the basic Cd concentration of $0.08 \mu \mathrm{g} \mathrm{l}^{-1}$. This was determined by flameless atomic absorption spectrometry after Kremling and Petersen (1981). The quartz bottles were put into a rotating Infors-incubator with an illumination of $115 \mu \mathrm{E} \mathrm{m}^{-2} \mathrm{~s}^{-1}$ and a light: dark cycle of $12: 12 \mathrm{~h}$. The temperature was kept at $20^{\circ} \mathrm{C}$.

During the first $70 \mathrm{~h}$ of algal growth a $50 \mathrm{ml}$ sample was taken every $2 \mathrm{~h}$ with metal-free medical syringes and filtered through 2 superimposed $0.45 \mu \mathrm{m}$ membrane filters. The content of the filter and $0.5 \mathrm{ml}$ filtrate were measured for radio nuclide concentrations, according to Rabsch and Elbrächter (1980). The 20 standard deviation for each nuclide was within $2 \%$. Amounts of metal were calculated from net counting rates and specific activity.

During daytime, usually every $1 \mathrm{~h}$, additional $50 \mathrm{ml}$ subsamples were taken and incubated after addition of $74 \mathrm{kBq}{ }^{14} \mathrm{CO}_{2}$ for $4 \mathrm{~h}$ in Sovirel flasks to determine carbon fixation rates. After incubation the subsamples were filtered over 2 superimposed $0.45 \mu \mathrm{m}$ Sartorius membrane filters. Radioactivity of the 2 filters was counted separately in a BF 5000 (Berthold) scintillation counter. The lower filter was a routine check for metal adsorption and algal leakage. Additionally, $0.5 \mathrm{ml}$ of the water was analysed for total radioactivity. ${ }^{14} \mathrm{CO}_{2}$ fixation was calculated using the following equation:

$$
\operatorname{mg~Cl} l^{-1}=\frac{\mathrm{dpm} \mathrm{a} \cdot 1.05 \cdot 20 \mathrm{mg} \mathrm{Cl}^{-1}}{\mathrm{dpm} \mathrm{b} \cdot \mathrm{f}}
$$

where a $=\mathrm{dpm}{ }^{14} \mathrm{C}$ on the 2 filters corrected for adsorption of ${ }^{14} \mathrm{C}$ background; $\mathrm{b}=\mathrm{dpm}{ }^{14} \mathrm{C}$ added to the subsample; $1.05=$ discrimination factor (Parsons and Strickland, 1962); $\mathrm{f}=$ counting efficiency. Counting efficiency was checked by the internal standard method, and the quench was routinely examined by external channel ratio. Incubation period lasted $4 \mathrm{~h}$, so that results of different periods overlapped. For calculation of hourly carbon fixation rates, geometric mean values were calculated.

One experimental check of the standard variation of the ${ }^{14} \mathrm{C}$-method resulted in $\pm 7 \%$ for 40 subsamples, distributed over the whole area of the incubator. Carbon fixation rate per cell and metal accumulation per cell were obtained from additional cell numbers taken from regression curves; these were calculated from cell counts carried out once or twice a day.

During the 3 periods of intensive measurement, bacterial activity was measured twice a day; $10 \mathrm{ml}$ 
subsamples were incubated at noon and at midnight for $1 \mathrm{~h}$ with $925 \mathrm{~Bq}{ }^{14} \mathrm{C}$ glucose $=0.02 \mu \mathrm{g} \mathrm{C}$. Three replicates were run. Following incubation, samples were fixed with formaldehyde to a final concentration of $1 \%$, filtered through $0.2 \mu \mathrm{m}$ Sartorius membrane filters, and the radioactivity on the filters was measured in a BF 5000 (Berthold) liquid scintillation counter.

Numbers of algal cells were counted once or twice a day with an inverted microscope. Intact cells and empty thecae were distinguished. At least 500 cells were counted to give a standard variation below $10 \%$.

The change of zinc content per cell with time was smoothed by a five-point weighted average smoothing function. The equation for the first and last three points is:

$$
\mathrm{C}_{\mathrm{p}}=\frac{\mathrm{C}_{\mathrm{p}-1}+2 \mathrm{C}_{\mathrm{p}}+\mathrm{C}_{\mathrm{p}+1}}{4}
$$

For all other points we used:

$$
C_{p}^{\prime}=\frac{C_{p-2}+4 C_{p-1}+6 C_{p}+4 C_{p+1}+C_{p+2}}{16}
$$

where $C_{p}{ }^{\prime}=$ zinc content at time $\mathrm{p}$ after smoothing; $\mathrm{C}_{\mathrm{p}}=$ zinc content at time $\mathrm{p}$. The difference between original value and smoothed value was used to calculate a standard deviation $\left(\mathrm{S}_{\mathrm{d}}\right)$. It ranged from \pm 0.6 to $2 \%$, except for the third measuring period where it rose to $\pm 20 \%$. A significance test for minima and maxima shows that they were significantly different over the whole period. A Fourier analysis found maxima in a $24 \mathrm{~h}$ interval.
A second intensive period of measurement in which subsamples were taken hourly was carried out at a later stage of experimental growth; a third phase, at the beginning of the stationary phase.

An additional experiment was conducted in order to study time-dependent accumulation of $\mathrm{Cd}$ by cells of Prorocentrum micans. Culture conditions were the same as for the long-term experiment. Cell density was $0.9 \cdot 10^{6} 1^{-1}$. Six Cd concentrations $(0.08,2,10,20,30$ and $50 \mu \mathrm{g} \mathrm{Cd}^{-1}$ ) were tested over a period of $1 \mathrm{~d}$. At the beginning subsampling was done at very short time intervals. Fifty $\mathrm{ml}$ samples were filtered through 2 superimposed $0.45 \mu \mathrm{m}$ Sartorius membrane filters and were processed as described previously.

\section{RESULTS}

\section{Growth}

Fig. 1 shows growth curves of Prorocentrum micans in control and Cd-containing bottles. Logarithmic growth lasted about $200 \mathrm{~h}$. The cells then entered the stationary growth phase.

Generation times (Table 1) ranged between 60.6 and $77.0 \mathrm{~h}$; they were shortest in the control. In control and culture (containing $1 \mu \mathrm{g} \mathrm{Cd}^{-1}$ ) cell numbers increased 10 -fold until the end of the experiment, whereas in the cultures with 2 and $10 \mu \mathrm{g} \mathrm{Cd} \mathrm{l}^{-1}$ they multiplied 5 to 6 -fold.

Fig. 2 represents data on the sum of cells (living cells and empty thecae). There was a striking increase of empty thecae in all bottles during the whole period of
Fig. 1 Prorocentrum micans. Growth curves in different Cdconcentrations. Symbols indicate counted living cells; lines the computed regression

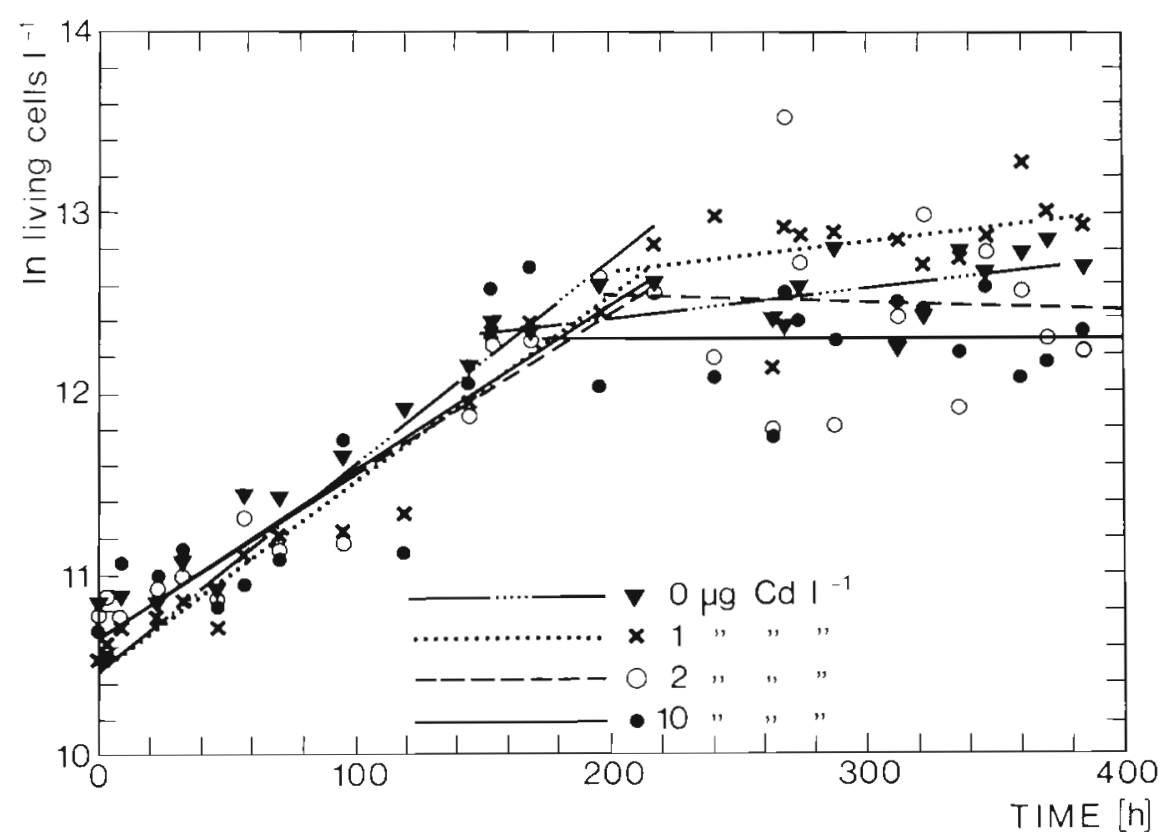


Table 1. Prorocentrum micans. Cd-concentration, cell numbers at beginning and end of experiment, and mean generation times calculated from regression curves during exponential growth

\begin{tabular}{|cccc|}
$\begin{array}{c}\text { Cd- } \\
\text { concentration } \\
\left(\mu \mathrm{g}^{-1}\right)\end{array}$ & $\begin{array}{c}\text { No. of living } \\
\text { cells } \\
\left(\text { cells } ~^{-1}\right)\end{array}$ & $\begin{array}{c}\text { Generation } \\
\text { time } \\
(\mathrm{h})\end{array}$ \\
\hline & start & final & \\
0.08 & 34822 & 347597 & $60.6 \pm 9.0$ \\
1.08 & 35782 & 319234 & $67.1 \pm 4.2$ \\
2.08 & 42247 & 247246 & $77.0 \pm 6.5$ \\
10.08 & 42608 & 220141 & $75.4 \pm 10.1$ \\
\hline
\end{tabular}

the experiment. The strong variation in numbers of living cells (Fig, 1) attained maximum values in bottles with 2 and $10 \mu \mathrm{g} \mathrm{Cd} 1^{-1}$.

\section{Uptake of carbon}

Carbon fixation rate per hour and per cell is illustrated in the lower parts of Fig. 3,4, and 5. The values varied between 20 and $120 \mathrm{pg} \mathrm{C} \mathrm{h}^{-1} \mathrm{cell}^{-1}$. Although light intensity in the incubator did not change during daytime, carbon fixation rates witness a pronounced daily rhythm. As we took numerous subsamples at

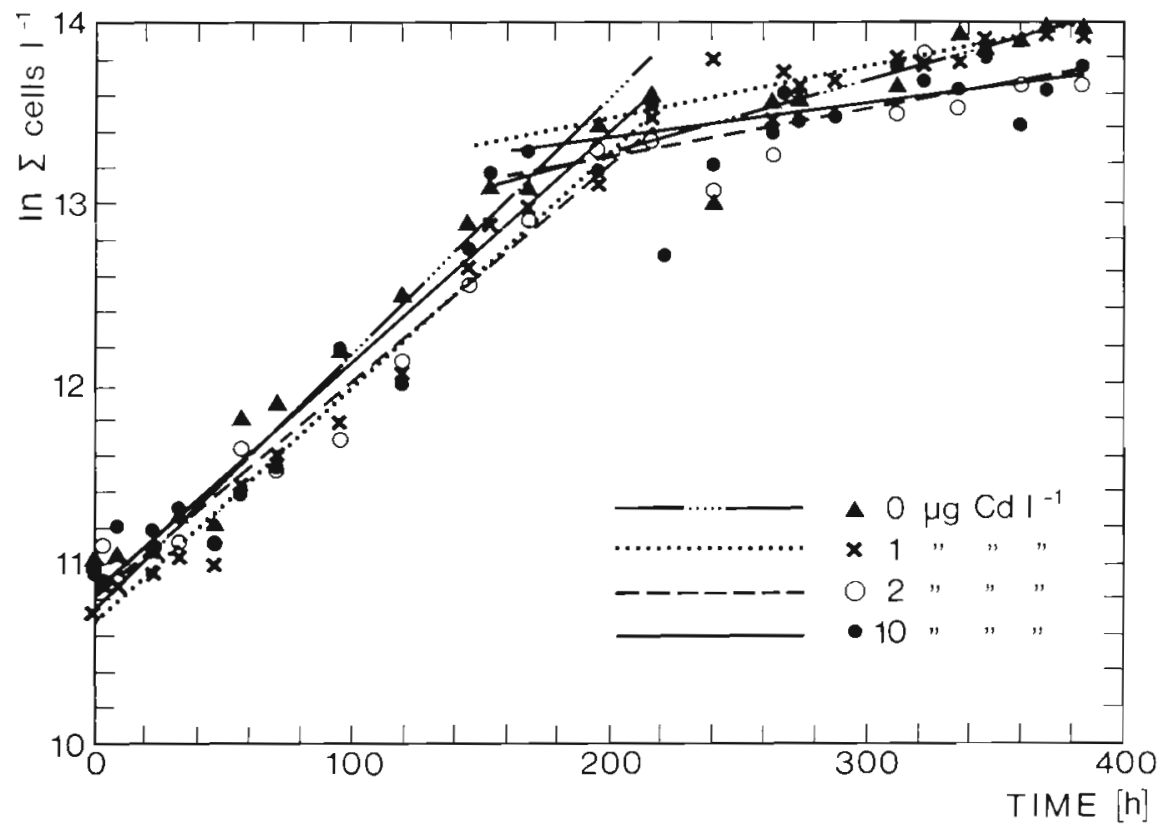

Fig. 2. Prorocentrum micans. Sum of cells in different $\mathrm{Cd}$-concentrations. Symbols: sum of living cells and empty thecae; lines: computed regression

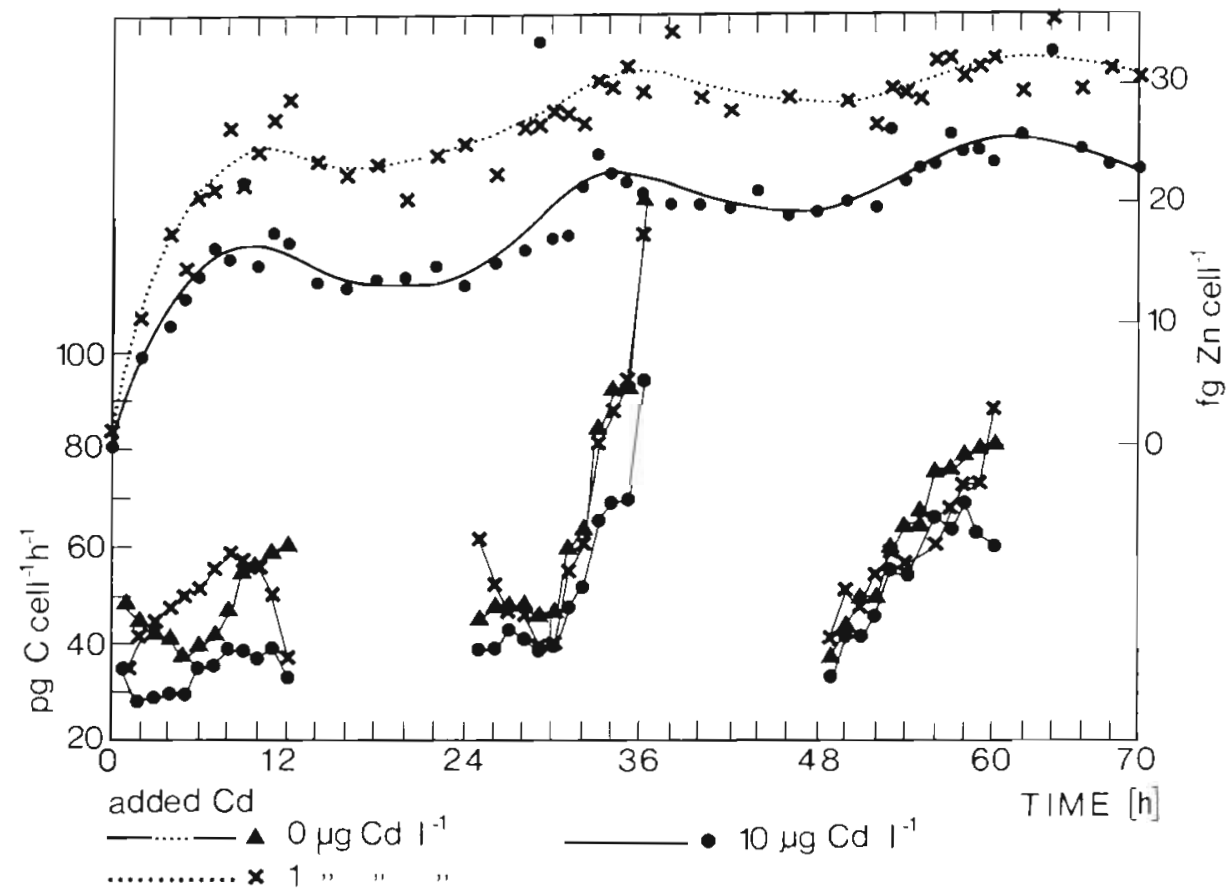

Fig. 3. Prorocentrum micans. Upper: measured zinc content cell ${ }^{-1}$ after addition of 1 and $10 \mu \mathrm{g} \mathrm{Cd}$ $\mathrm{l}^{-1}$ during the first $70 \mathrm{~h}$. Lower: carbon fixation rate cell ${ }^{-1}$, calculated from 3 overlapping samples in control and in bottles containing 1.08 and $10.08 \mu \mathrm{g} \mathrm{Cd}$ 
Fig. 4. Prorocentrum micans. Upper: measured zinc content cell ${ }^{-1}$ in bottles containing 1.08 and $10.08 \mu \mathrm{g} \mathrm{Cd}$ during end of logarithmic growth phase, 210 to $280 \mathrm{~h}$ after inoculation. Lower: carbon fixation rate cell ${ }^{-1}$, calculated from overlapping samples, in control and in bottles containing 1.08 and $10.08 \mu \mathrm{g} \mathrm{Cd}$
Fig. 5. Prorocentrum micans Upper: measured zinc content cell ${ }^{-1}$ in different $\mathrm{Cd}$ concentrations during stationary phase. Lower: carbon fixation rate cell ${ }^{-1}$, calculated from 3 overlapping samples in different $\mathrm{Cd}$-concentrations
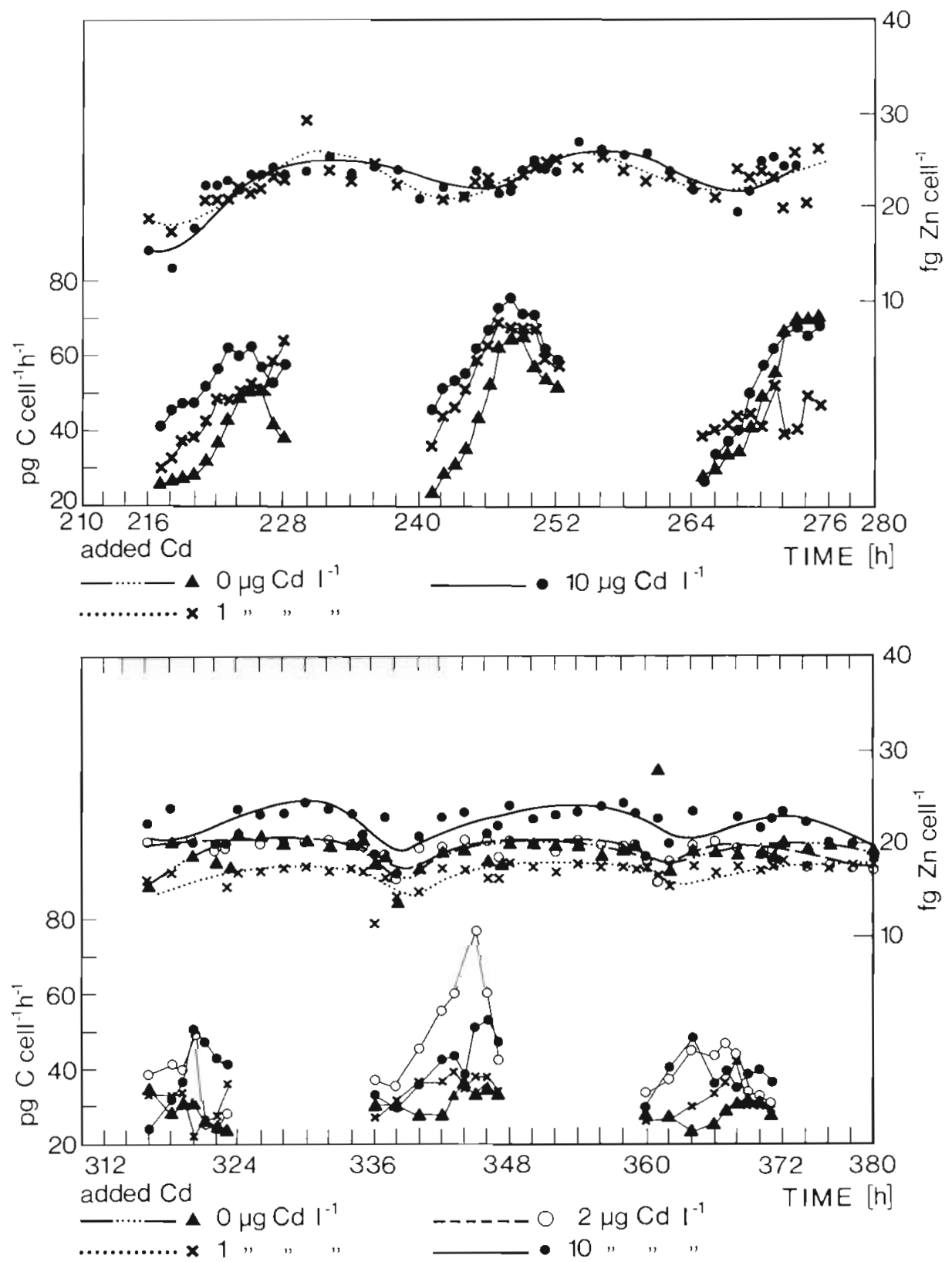

short time intervals and the values showed clear trends without strong variations we think that the single measurements are valid, although we cannot give exact information on standard deviation (We only mentioned under 'Material and methods' single standard variations for the different measurements). Normally, Prorocentrum micans had the highest carbon fixation rate $8 \mathrm{~h}$ after illumination started. The high increase in the afternoon of the second day is caused by synchronized preparation of cell division in all 3 flasks. Cell volume was enlarged prior to division and this resulted in a higher production of the single cell. Unfortunately, synchronized growth lasted only for the first 2 to $3 \mathrm{~d}$. The effect of cadmium manifested itself only during the first $3 \mathrm{~d}$ in a slight depression of the productivity with rising cadmium concentration. During the stationary phase the carbon fixation rate was lower than in the exponential phase and the daily rhythm was less dynamic.

\section{Uptake of zinc}

The change of zinc content in the cells is illustrated in the upper part of Fig. 3 to 5. The values lie in the range of 10 to $30 \mathrm{fg} \mathrm{Zn} \mathrm{cell}^{-1}$. Of the total amount of $\mathrm{Zn}$ in solution $0.4 \%$ was initially bound to the cells; this amount increased to $20 \%$ at the end of the experiment. We were not able to demonstrate any difference in $\mathrm{Zn}$ 
content of intact cells and empty thecae. We observed an interesting trend in metal content per cell: it increased during the day and more or less clearly decreased at night with maxima every $24 \mathrm{~h}$. This rhythm was most obvious during the first $3 d$, suggesting that it corresponded to the metabolism of living cells.

A strong increase of carbon fixation per cell at the end of the second day as a consequence of the cells' preparation to divide was not accompanied by a comparable increase in the zinc content of cells. The zinc content of the dinoflagellate was affected by the cadmium concentrations in the surrounding water. During the first $3 \mathrm{~d}$ it was higher in the bottle with lower cadmium concentration, thereafter it decreased in the course of the experiment. This might have been due to replacement of $\mathrm{Zn}$ by $\mathrm{Cd}$ in the cell.

\section{Uptake of cadmium}

Cadmium content in the cells increased along with cadmium concentration in the water. Concentrations in the water ranged from 0.08 to $10 \mu \mathrm{g} \mathrm{l}^{-1}$ and the cadmium content in the cells varied by almost 2 orders of magnitude between $10^{-15}$ and $10^{-13} \mathrm{~g} \mathrm{Cd} \mathrm{cell}^{-1}$. Expressed as percentage of total $\mathrm{Cd}$ in solution, the particle-bound cadmium changed from $2 \cdot 10^{-3} \%$ at the beginning of the experiment to $2 \%$ at the end. Fig. 6a illustrates the $\mathrm{Cd}$ content per cell as a percentage of the starting value. This type of presentation was chosen for better comparison of the different $\mathrm{Cd}$ contents and to avoid a logarithmic scale, which tends to obscure oscillations. The starting value was calculated from the relation between particle bound $\mathrm{Cd}$ and time by extrapolating to $t=0$ using the values of the first $3 \mathrm{~d}$. At the beginning of the experimental period, the Cd content per cell also showed a slight rhythm, with maxima every $26 \mathrm{~h}$. During the light phase the metal was accumulated in the cells, whereas during the dark phase its content decreased. During the experiment, there was a slight increase in the metal content of the cells.

\section{Excess of zinc in relation to cadmium}

To compare the relation of $\mathrm{Zn}$ and $\mathrm{Cd}$ in the cells, enrichment factors (EF) are used. The enrichment factor is defined as the ratio between the content in the algae and the concentration in water:

$$
E F=\frac{C_{A}}{A_{V}} \cdot \frac{W_{V}}{C_{W}}
$$

where $C_{A}=$ content of metal in algae; $A_{v}=$ volume of algae; $W_{v}=$ volume of water; $C_{w}=$ concentration of metal in water. For a study of the trend of EF during the experiment it is irrelevant whether contents are expressed on an alga volume or weight basis, because microscopically we could not observe changes in cell volume under the influence of $\mathrm{Cd}$.

Fig. $6 \mathbf{b}$ demonstrates the relation of the enrichment factor of $\mathrm{Zn}$ to that of $\mathrm{Cd}$ over the entire experimental period. The relation of the 2 enrichment factors expresses how many times the accumulation of zinc was higher than that of cadmium (Zn-excess). Fig. 6b shows clearly the correspondence of data in regard to the daily rhythm in the different contaminated cultures. In the first $3 \mathrm{~d}$, the percentage of cadmium

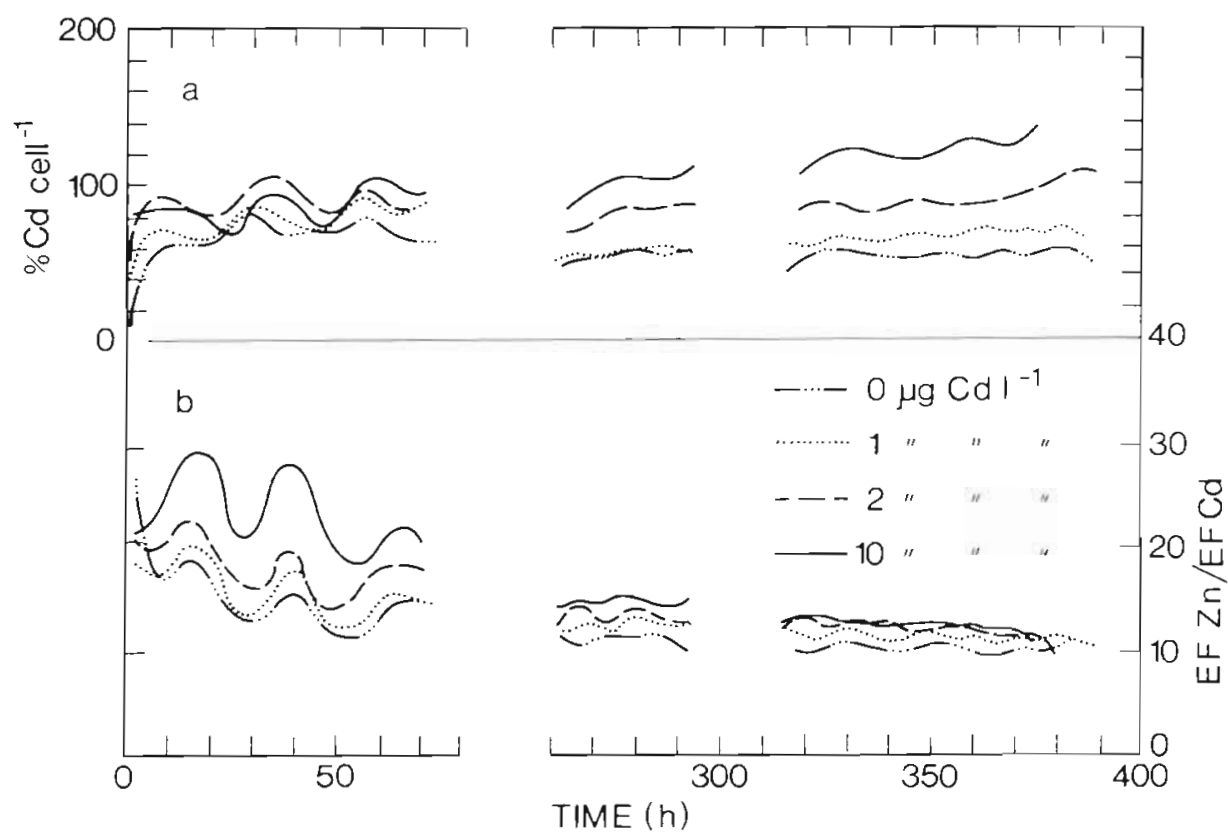

Fig. 6. Prorocentrum micans (a) Cd-content cell ${ }^{-1}$, expressed as percentage of the starting value, in control and 3 bottles containing Cd. (b) Ratio of the enrichment factors of zinc and cadmium in control and 3 bottles containing $\mathrm{Cd}$ 
increases and also the Zn-excess shows a daily cycle which becomes more and more reduced towards the end of the experiment. The zinc excess expresses clearly that $\mathrm{Zn}$ is accumulated faster by the cells than $\mathrm{Cd}$, and that $\mathrm{Zn}$ is then slowly replaced by $\mathrm{Cd}$.

\section{Relation between particulate and dissolved cadmium}

The rhythm in $\mathrm{Zn}$ and $\mathrm{Cd}$ accumulations reveals that the concentrations of particle-bound metals depend upon metabolic processes. Fig. 7 depicts results from an additional experiment in which the time dependence of the Cd content of the cells as well as its relation to different $\mathrm{Cd}$ concentrations in the water was tested. The different curves stand for different sampling times after starting the experiment which was also carried out with Prorocentrum micans in water prepared as described. The values after $60 \mathrm{~h}$ are the results from the long-term experiment.

After $1 \mathrm{~min}$, the level of cadmium bound to the cells

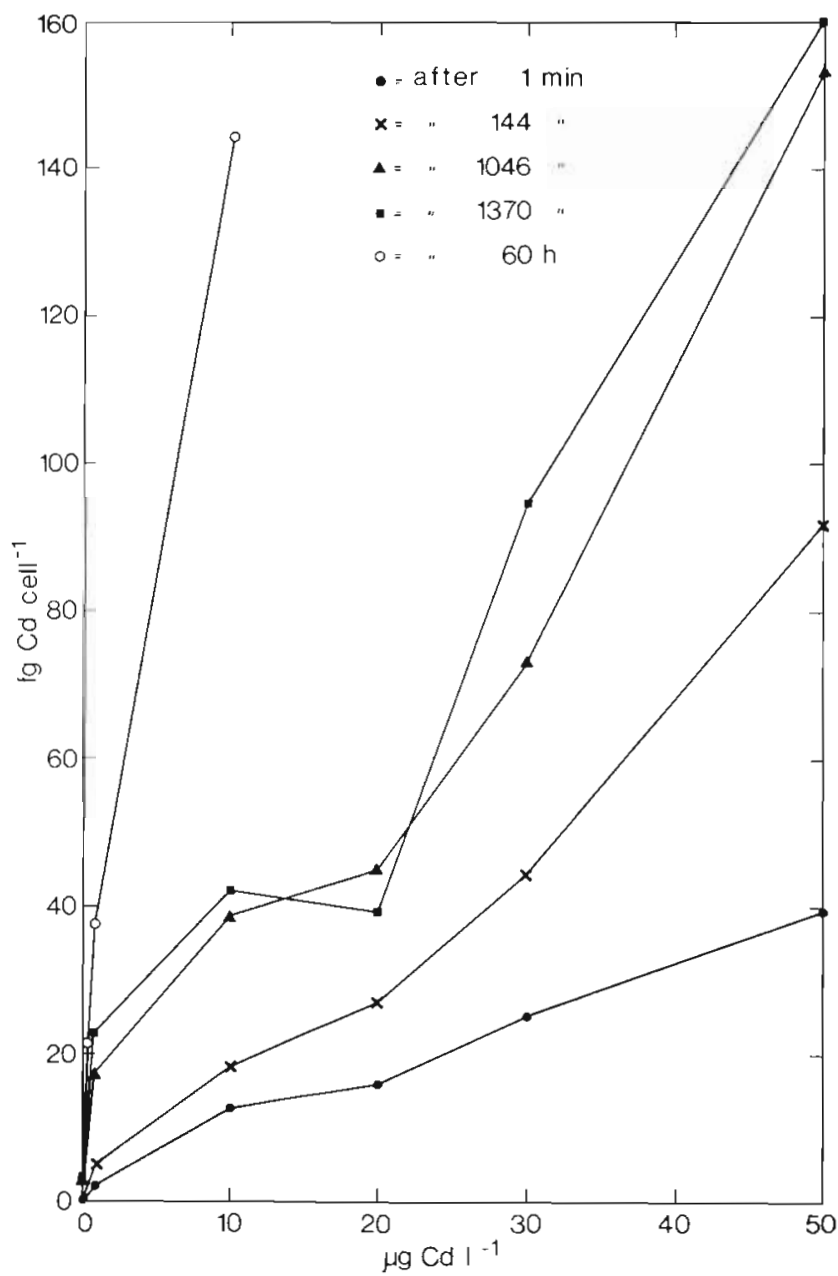

Fig. 7. Prorocentrum micans. Relation of cellular bound and dissolved $\mathrm{Cd}$ at different times was proportional to the cadmium concentrations in the water. This can be expected if the adsorption of metal to the cells would follow the Langmuir adsorption isotherm:

$$
\mathrm{C}_{\mathrm{ad}}=\mathrm{C} \frac{\mathrm{k} \cdot \mathrm{C}_{\mathrm{s}}}{1+\mathrm{k} \cdot \mathrm{C}}
$$

where $\mathrm{C}_{\mathrm{ad}}=$ content of adsorbed metal in mol cell ${ }^{-1}$; $\mathrm{C}=$ metal concentration in water $\mathrm{mol}^{-1} ; \mathrm{k}=$ adsorption coefficient; $\mathrm{C}_{\mathrm{s}}=$ content of adsorbed metal at saturated level in mol cell-1.

A stronger increase of cellular bound $\mathrm{Cd}$ with time is observed at concentrations well below $10 \mu \mathrm{gl}^{-1}$. To test more exactly whether the observed decrease of the

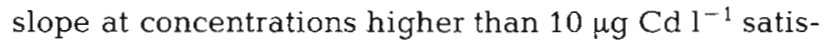
fies the Langmuir adsorption curve at a beginning saturation level, we have plotted (Fig. 8) the enrichment factor (EF) against the metal concentration in the water. The enrichment factor corresponds to the expression $\mathrm{C}_{\mathrm{ad}} / \mathrm{C}$ in the Langmuir equation. Clearly from 10 to $50 \mu \mathrm{g} \mathrm{l}^{-1}$ metal accumulation is proportional to ambient concentrations in the water and no saturation occurs. Below $10 \mu \mathrm{g} \mathrm{l}^{-1}$, enrichment factors increase more than would be expected if uptake followed only adsorption.

\section{Bacterial activity}

Fig. 9 illustrates bacterial uptake of radioactive labelled glucose added to subsamples and incubated for $1 \mathrm{~h}$. Uptake was measured once during the light

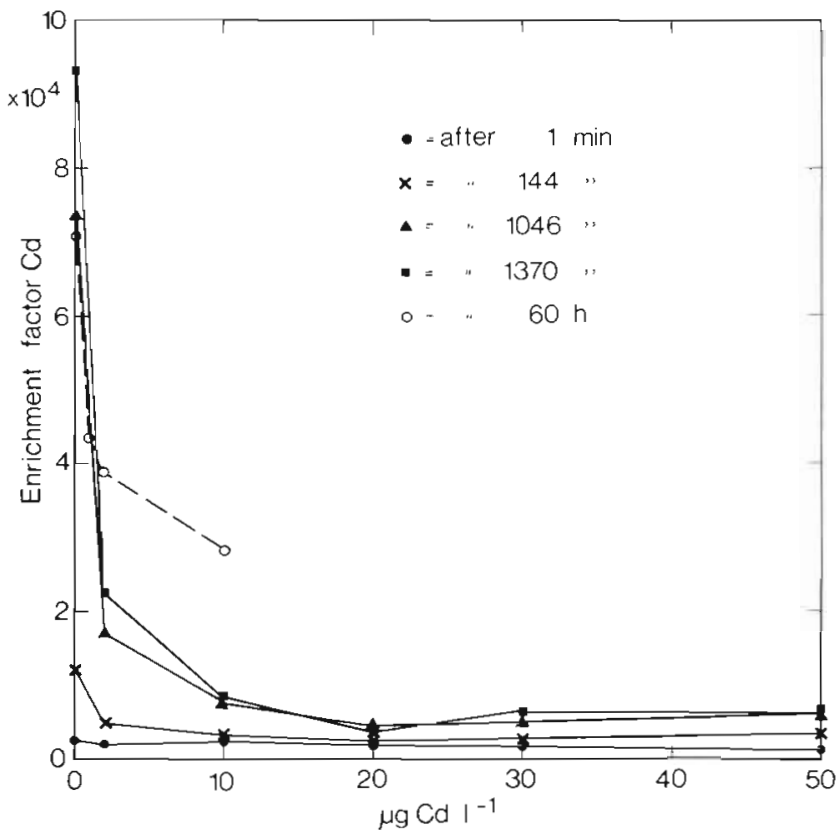

Fig. 8. Enrichment factors of $\mathrm{Cd}$ as a function of time and dissolved $\mathrm{Cd}$ 


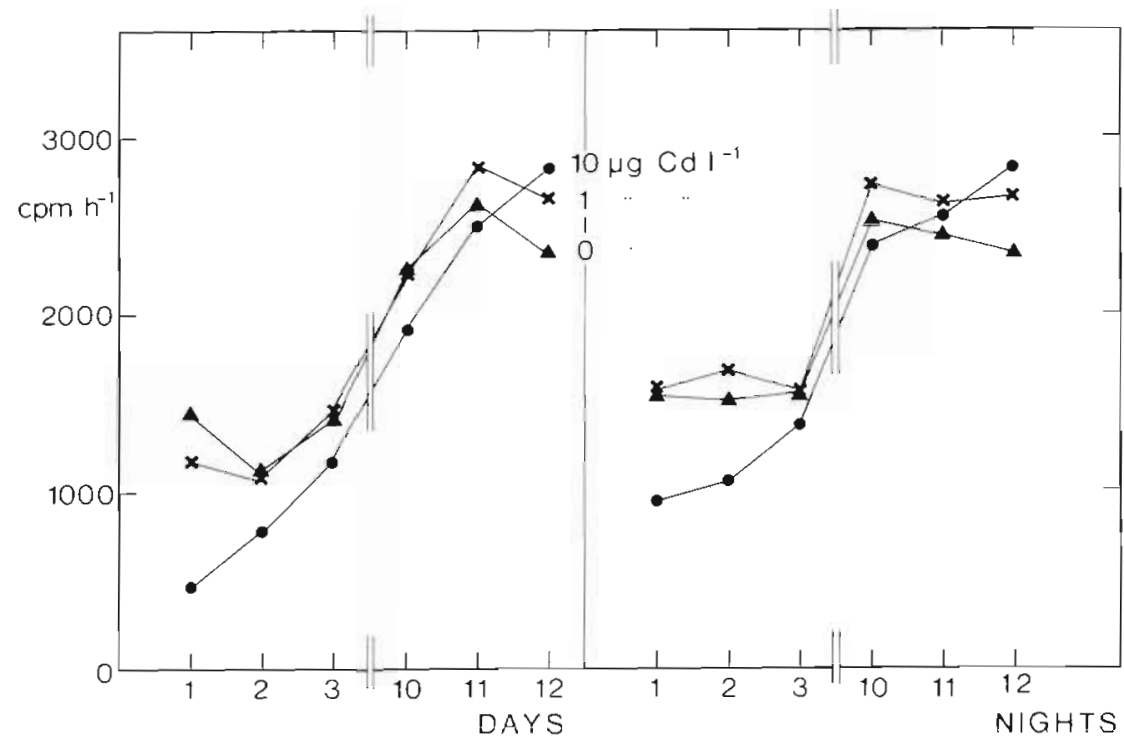

Fig. 9. Bacterial uptake of radioactive labelled glucose in different Cd-concentrations

period and at night. Bacterial activity reveals a lag phase of 2 to $3 \mathrm{~d}$ at $10 \mu \mathrm{g} \mathrm{Cd} \mathrm{l}^{-1}$. In the course of the experiment this inhibition decreased, and the last day's uptake of labelled glucose was slightly higher in water with the highest Cd-concentration.

\section{DISCUSSION}

Elbrächter (1976) studied the growth of Prorocentrum micans in seawater with different concentrations of nutrients. Mean generation time in filtered North Sea water without added nutrients was $2 \mathrm{~d}$. Cell density attained $735 \cdot 10^{3}$ cells $1^{-1}$ in the stationary growth phase. No relation between generation time and nutrient concentration could be found, but cell densities in the stationary growth phases were different. In our experiments lower cell densities, at the end of the experiments, ranged from $220 \cdot 10^{3}$ to $347 \cdot 10^{3}$ cells $1^{-1}$. Generation times were between 60 and $77 \mathrm{~h}$, the longer generation times occurring at higher dissolved Cd-concentrations (Table 1). Kayser and Sperling (1980) found generation times of $P$. micans in filtered North Sea water of 1.9 d; this fits well with Elbrächter's data (1976) but the final cell density was considerably higher $\left(12 \cdot 10^{6}\right.$ cells $\left.l^{-1}\right)$. Cultures containing between

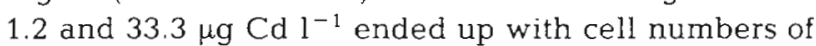
$10^{5}$ and $10^{6} \mathrm{l}^{-1}$. This shows that a concentration of $1.2 \mu \mathrm{g} \mathrm{Cd}^{-1}$ inhibits the growth of $P$. micans severely. The generation time at $1.2 \mu \mathrm{g} \mathrm{Cd} \mathrm{l^{-1 }}$ was $5.4 \mathrm{~d}$. Although we obtained obvious differences between control and the different $\mathrm{Cd}$ concentrations, these differences are considerably smaller than described by Kayser and Sperling (1980). The generation time in our experiments increased with $\mathrm{Cd}$ concentrations. The generation time in control was fairly high. This is due to the use of almost DOC-free water. Under similar DOC depleted conditions, Barber et al. (1971) found a smaller specific growth rate than in normal cultures. From the literature (Rai et al., 1981) we know that the availability, and thus the toxicity, of heavy metals to algae depends strongly on environmental conditions. Since we wanted to investigate the accumulation and reaction of relatively small contamination of heavy metals, we had to exclude chelating agents to a certain extent, well knowing that Prorocentrum micans requires organic substances for optimal growth. The control bottle with very low levels of heavy metals contained the same DOC-depleted water, thus we were able to compare the results.

Davies (1978) conducted growth experiments on Isochrysis galbana in concentration ranging from 0 to $105 \mu \mathrm{g} \mathrm{Cd} \mathrm{l}^{-1}$. He found strong depressions of growth after $16 \mathrm{~d}$ of the culture experiments at concentrations above $44 \mu \mathrm{g} \mathrm{Cd}^{-1}$ and reports a relation between the quotient of the specific growth rate of Cd-containing cultures and of the Cd-free control to the Cd-content of the cells. This relation depended upon the nutritional level of the batch culture, indicating that the cells become more susceptible to the metal as the nutrients are consumed and the cells change from protein metabolism to that of carbohydrates and lipids, which do not complex the metal ions as efficiently as proteins. Cd values per biovolume found by Davies (1978) were in the range of 40 to $140 \mathrm{ag} \mathrm{Cd} \mu \mathrm{m}^{-3}$, whereas in our experiments $\mathrm{Cd}$-contents ranged from 4 to $320 \mathrm{ag} \mathrm{Cd}$ $\mu \mathrm{m}^{-3}$

One further effect of $\mathrm{Cd}$ on Prorocentrum micans was the increase of empty thecae and of cells 
surrounded by protoplasm strings occupied later by bacteria. It is difficult to explain the appearance of numerous empty thecae and their increase with the number of living cells (Fig. 2). Several times we observed stages of dividing cells just getting rid of their thecae. This is not the normal form of cell division in dinoflagellates. Normally each daughter cell keeps 1 theca of the mother cell and then produces a new one. Since additional experiments showed that the empty thecae were mainly produced during division, we assume that one effect of metal pollution might be a defect in the division cycle. Although empty thecae also occurred in the control, their appearance was more frequent in the contaminated water. A similar observation was reported by Prévot (1978a) who found that the number of bursting thecae is higher under the influence of cadmium. According to Saifullah (1978), who studied the effect of $\mathrm{Cu}$ on the dinoflagellate Scrippsiella faeroense, the thecae burst quickly, releasing their protoplast, which in turn tended to produce a new envelope that again was occupied by the metal. Kayser (1977) described similar observations for the same organism exposed to $\mathrm{ZnSO}_{4}$. In addition we found that the number of living cells fluctuated strongly (Fig. 1), especially in bottles with 2 and $10 \mu \mathrm{g} \mathrm{Cd}^{-1}$. The curve of the sum of cells does not support this fact. This phenomenon might also be due to the production of empty thecae. The daughter cells, which must develop new thecae after division, may stick with their protoplasts to the glass wall resulting in appearance changes from sample to sample.

Interestingly, in the control, carbon fixation rate is highest during the first $3 \mathrm{~d}$, but lowest during the last $3 \mathrm{~d}$. There is a discrepancy in the amount of living cells in control and Cd-contaminated water, but nevertheless the diminished number of living cells in the contaminated water witnesses a higher efficiency in the carbon fixation rate. It remains to be investigated whether the metabolism is really accelerated or whether it only seems to be more efficient, e.g. because of the damage of the respiratory system. In the latter case primary products would accumulate since they cannot be used for energy metabolism. Until the end of the log growth phase, there was a clear rhythm of carbon fixation during the day. The maximum of the carbon fixation rate occurs in the afternoon; this cycle prevailed in all bottles, except for the first day where the rhythms were not parallel in the 3 bottles. Therefore carbon fixation rate as criterion for the effects of different Cd-concentrations may be problematic in short-term incubations.

The results further reveal metal accumulation. Since the rhythms become less obvious with increasing population age, it seems likely that metal accumulation is due to metabolic processes. An indirect influence might exist through differences in protein biosynthesis. As Davies (1978) proposed that metal uptake by the cells is diffusion-controlled and governed by a concentration gradient across the cell membrane, it might be possible that the accumulation of metal ions at the cell membrane is dependent upon the cycles of protein synthesis in the cell.

Table 2 lists enrichment factors (EF) and zinc excess (ratio of EF of $\mathrm{Zn}$ to EF of Cd) after 60 and $300 \mathrm{~h}$. Maximum enrichment factors occur at the lowest cadmium concentration during exponential growth $(60 \mathrm{~h})$. This is supported by the experiment shown in Fig. 7

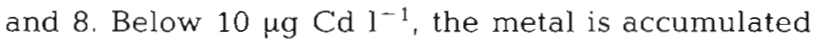
more strongly than one would expect from the linear part of a Langemuir adsorption isotherm.

Thus, growth and physiology of the cells might be severely impaired at and above $10 \mu \mathrm{g}^{-1}$. Further Cd accumulation with time might then be due to further adsorption to morphologically changed cells or to diffusion. The intensive uptake at lower concentrations depends upon actively metabolizing cells, which influence the accumulation of cadmium directly or indirectly. The comparison of the 24 and $60 \mathrm{~h}$ values shows that cells at low concentrations are in equilibrium after $24 \mathrm{~h}$. A limitation of available metal ions (which would result in a similar graph at very low concentrations, e.g. $0.1 \mu \mathrm{g} \mathrm{Zn} \mathrm{l}^{-1}$ and $80 \mathrm{ng} \mathrm{Cd} \mathrm{l}^{-1}$ ) can be excluded because during Day 1 only $1 \%$ of total zinc and $0.1 \%$ of total cadmium were accumulated. At least $2.5 \%$ of

Table 2. Comparison of enrichment factors (EF) of $\mathrm{Cd}$ and $\mathrm{Zn}$ during exponential growth and during the stationary phase

\begin{tabular}{|lccrrr|}
\hline Cd concentration $\left(\mu \mathrm{g} \mathrm{l}^{-1}\right)$ & & 0.08 & 1.08 & 2.08 & 10.08 \\
\hline & & 71035 & 43940 & 38597 & 28680 \\
Exponential growth & EF Cd & 643800 & 646400 & 643000 & 585600 \\
after $60 \mathrm{~h}$ & EF Zn & 9.1 & 12.3 & 16.4 & 20.4 \\
& EF Zn & & & 31460 & 28880 \\
EF Cd & EF Cd & 41500 & 27700 & 417500 & 458800 \\
Stationary growth & EF Zn & 545340 & 488200 & 13.3 & 15.9 \\
after $300 \mathrm{~h}$ & EF Zn & 13.1 & 12.5 & & \\
& EF Cd & & & & \\
\hline
\end{tabular}


$\mathrm{Cd}$ and $17 \%$ of $\mathrm{Zn}$ should be available in ionic form at the $\mathrm{pH}$ and salinity of the culture medium (Zirino and Yamamoto, 1972).

Kayser and Sperling (1980) also found the highest concentration factor at the lowest Cd-concentration, $\mathrm{CF}=9852$ at $0.1 \mu \mathrm{g} \mathrm{Cd} \mathrm{l}^{-1}$. We obtained $\mathrm{EF}=71035 \mathrm{at}$ $0.08 \mu \mathrm{g} \mathrm{l}^{-1}$ after $60 \mathrm{~h}$. Whereas Kayser and Sperling (1980) report an increase of CF with time, we found a decrease of $\mathrm{EF}$ in all $\mathrm{Cd}$-concentrations investigated. The difference in the magnitudes of EF is, besides a small discrepancy according to the volume used, due to the different DOC-levels.

The way in which light influences metal uptake at the beginning of the experiment indicates the metabolites (i. e. ATP) produced during photosynthesis might be involved. Similar observations were made by Gipps and Coller (1980) for cadmium by Chlorella pyrenoidosa and by Matzku and Broda (1970) and Findenegg et al. (1971) for zinc.

In an additional experiment we inhibited photosynthesis by DCMU (3[3,4-dichlorophenyl]-1,1-dimethylurea) and measured Cd accumulation by Prorocentrum micans. The results showed no influence upon the Cduptake. However, from the information at hand we cannot decide whether metal uptake is generally energy dependent or not; there are other metabolic pathways involved in providing energy. Their role in metal uptake remains to be tested. There is also the possibility that periodic changes in the charge of the membrane may be responsible for increase or decrease of cellular metal content. An argument in favour of a specific regulation of metal transport by the cell might be the different behaviour of $\mathrm{Zn}$ and $\mathrm{Cd}$.

Enrichment factors of $\mathrm{Zn}$ are rather constant and 10 to 20 times higher than those of $\mathrm{Cd}$. Even from its position in the electro-negativity sequence, $\mathrm{Cd}$ should replace $\mathrm{Zn}$. The time relation of zinc excess (Fig. 6) reveals a more pronounced daily rhythm than $\mathrm{Zn}$ or $\mathrm{Cd}$ itself. This leads to a shifting in the daily rhythm of bound metals. There is a difference of about $2 \mathrm{~h}$ between the daily maxima of $\mathrm{Zn}$ and $\mathrm{Cd}$. Uptake of $\mathrm{Zn}$ is faster. Possibly, due to competition between $\mathrm{Zn}$ and $\mathrm{Cd}$ for cellular binding sites and to faster binding of $\mathrm{Zn}$, zinc assists in protecting the organism against cadmium. According to Braek et al. (1980) Zn-ions reduce the toxicity of $\mathrm{Cd}$-ions for Skeletonema costatum. To prove the expectation that $\mathrm{Cd}$ uptake is using the zinc path, enzymatic tests are required.

The bacterial population can adapt to the high concentration of cadmium. At the beginning, bacterial uptake of labelled glucose is reduced at a cadmiumconcentration of $10 \mu \mathrm{g} \mathrm{l}^{-1}$, whereas at the end of the experiment, the bacterial activity was slightly higher than in the control. Bacteria either adapted to the metal concentration or were stimulated by higher levels of dissolved organic matter provided by higher algal mortality, or a Cd resistant population was favoured.

In an estuary Thormann and Weyland (1979) found a variety of bacteria with differing sensitivities to heavy metals ( $\mathrm{Cd}$ and $\mathrm{Pb}$ ). Since they did not find a metal specific sensitivity it may be assumed that Cd-tolerant bacteria dominated.

We conclude that short-term experiments with natural water samples must be interpreted with care. Cd influences Prorocentrum micans growth. Although stronger $\mathrm{Zn}$ and $\mathrm{Cd}$ accumulations were measured at the beginning of the experiment, when cells were actively metabolising, the photosynthetic capacity was not significantly inhibited. The influence of $\mathrm{Cd}$ was demonstrated later during the experiment by accumulation of empty thecae and lower cell numbers at the end of the exponential growth phase. A suitable criterion for assessing the degree of metal pollution and its effect on phytoplankton might be the enrichment factor. It is related to the bio-availablity of metals species, and its magnitude indicates whether algal damage is to be expected.

Acknowledgements. We thank the 'Bundesminister für Forschung und Technologie' for financial support and are grateful to Professor Dr. J. C. Duinker, Professor Dr. G. Rheinheimer and Dr. B. Schneider for helpful discussions and for correcting an early version of our manuscipt.

\section{LITERATURE CITED}

Barber, R. T., Dugdale, R. C., Maclsaac, J. J., Smith, R. L. (1971). Variations in phytoplankton growth associated with the source and conditioning of upwelling water. Inv. Pesq. 35: 171-193

Berland, B. R., Bonin, D. J., Guérin-Ancey, O. J., Kapkov, V. J., Arlhag, D. P. (1977). Action de métaux lourds à des doses subléthales sur les caracteristiques de la brossance chez la diatomée Skeltonema costatum. Mar. Biol. 42: 17-30

Braek, G. S., Malnes, D., Jensen, A. (1980). Haevy metal tolerance of marine phytoplankton. IV. Combined effect of zinc and cadmium on growth and uptake in some marine diatoms. J. exp. mar Biol. Ecol. 42: 39-54

Canterford, G. S., Canterford, D. R. (1980). Toxicity of heavy metals to the marine diatom Dithylum brightwellii (West) Grunow, correlation between toxicity and metal speciation. J. mar. biol. Ass. U. K. 60: 227-242

Davies, A. G. (1978). Pollution studies with marine plankton. Part II Heavy metals. Adv. mar. Biol. 15: 381-508

Elbrächter, M. (1976). Population dynamic studies on phytoplankton cultures. Mar. Biol. 35: 101-209

Findenegg, G. R., Paschinger, H., Broda, E. (1971). Untersuchungen der Lichtabhängigkeit der Aufnahme von Rubidiun, Zink, Kobalt, Blei, Cer durch Chlorella nach einer Flußmethode. Planta 99: 163-173

Fisher, N. S., Jones, G. J. (1981). Heavy metals and marine phytoplankton: correlation of toxicity and sulfhydry Ibinding. J. Phycol. 17: 108-111 
Gipps, J. F., Coller, B. A. W. (1980). Effect of physical and culture conditions on uptake of cadmium by Chlorella pyrenoidosa. Austr. J. mar. Freshwat. Res. 31: 747-755

Jensen, A., Rystad, B. (1974), Heavy metal tolerance of marine phytoplankton. I. The tolerance of three algal species to zinc in coastal sea water J. exp. mar. Biol. Ecol. 15: 145-157

Kayser, H. (1977). Effect of zinc sulphate of mono- and multispecies cultures of some marine plankton algae. Helgoländer wiss. Meeresunters. 30: 682-696

Kayser, H., Sperling, K.-R. (1980). Cadmium effects and accumulation in cultures of Prorocentrum micans (Dinophyta). Helgoländer wiss. Meeresunters. 33: 89-102

Kremling, K., Petersen, H. (1981). The distribution of zinc, cadmium, copper, manganese and iron in waters of the open Mediterranean Sea. 'Meteor' Forschungsergeb. 23: 5-14

Matzku, S., Broda, E. (1970). Die Zinkaufnahme in das Innere von Chlorella. Planta 92: 29-40

Møhlenberg, F., Jensen, A. (1980). The ecotoxicology in fresh and seawater and water pollution with cadmium in Denmark. The National Agency of Environmental Protection, Charlottenlund

Parsons, T. R., Strickland, J. D. H. (1962). On the production of particulate organic carbon by the heterotrophic processes in sea water. Deep Sea Res. 8: 211-222

Prévot, P. (1978a). Sensibilité au cadmium d'un Dinoflagellé libre: Prorocentrum micans. E. IVes Journées Etud. Pollutions: 347-350, Antalya. C. J. E. S. M.

Prévot, P. (1978b). Etude de l'action intracellulaire du cad- mium: observations et mesures d'absorptions. Actualités de Biochimie Marine Colloque GABIM: 117-143

Prézelín, B. B., Ley, A. C. (1980). Photosynthesis and chlorophyll a flurorescence rhythms of marine phytoplankton. Mar. Biol. 55: 295-307

Rabsch, U., Elbrächter, M. (1980). Cadmium and zinc uptake, growth and primary production in Coscinodiscus granii cultures containing low levels of cells and dissolved organic carbon. Helgoländer wiss. Meeresunters. 33: $79-88$

Rai, L. C., Gaur, J. P., Jumar, H. D. (1981). Phycology and heavy-metal pollution. Biol. Rev. 56: 99-151

Rajendran, A., Sumitra-Vijayaragkovan, M. V. M., Wafär, M. V. M. (1978). Effect of some metal ions on the photosynthesis of microplankton and nannoplankton. Indian J. mar. Sci. 7: 99-102

Saifullah, S. M. (1978). Inhibitory effects of copper on marine dinoflagellates. Mar. Biol. 44: 299-308

Subba Rao, D. V. (1981). Growth response of marine phytoplankters to selected concentrations of trace metals. Bot. Mar. 24: 369-379

Sweeney, B. M., Prézelin, B. B. (1978). Circadian rhythms. Photochem. Photobiol. 27: 841-847

Thormann, D., Weyland, H. (1979). Beziehungen zwischen verschiedenen Brackwasser- und Meeresbakterien und der wachstumshemmenden Wirkung von Cadmium und Blei. Veröff. Inst. Meeresforsch. Bremerh. 17: 163-188

Zirino, A., Yamamoto, S. (1972). A pH dependent model for the chemical speciation of copper, zinc, cadmium and lead in seawater. Limnol. Oceanogr. 17: 661-671

This paper was submitted to the editor; it was accepted for printing on June 16, 1983 